\title{
Pepper Photosynthesis, Stomatal Conductance, Transpiration, and Water Use Efficiency Differ with Variety, Indigenous Habitat, and Species of Origin
}

\author{
John Erwin \\ Department of Horticultural Science, University of Minnesota, 1970 Folwell \\ Avenue, St. Paul, MN 55108
}

\author{
Tanveer Hussein \\ Institute of Horticultural Sciences, University of Agriculture, Agriculture \\ University Road, Faisalabad, Pakistan 38000
}

\author{
David J. Baumler \\ Department of Food Science and Nutrition, University of Minnesota, 1334 \\ Eckles Avenue, St. Paul, MN 55108
}

Additional index words. humidity, Capsicum, photosynthesis, temperature

\begin{abstract}
The instantaneous photosynthetic rate $\left(\mathrm{P}_{\mathrm{n}}\right)$, transpiration rate $(\mathrm{E})$, and stomatal conductance $\left(g_{S}\right)$ were measured for 33 outdoor-grown Capsicum varieties (varying in species of origin and indigenous habitat) between 29 July and 22 Aug. 2017 using a portable gas exchange meter. Cuvette leaf temperature $\left(T_{\text {leaf }}\right)$ and relative humidity $(R H)$ were recorded at that same time. $P_{n}$ differed from 3.6 to 3.7 for 'Malawi Piquante' and 'Korean Long Green' peppers to $16.3 \mu \mathrm{mol} \mathrm{CO} / \mathrm{C}^{2} / \mathrm{s}$ (fixed) for 'Thai Hot' peppers. The $g_{\mathrm{S}}$ differed from 0.01 to 0.05 among 13 varieties to $0.28 \mathrm{mmol} \mathrm{H}_{2} \mathrm{O} / \mathrm{m}^{2} / \mathrm{s}$ for 'Thai $\mathrm{Hot}$ ' peppers. $E$ differed from 0.43 to 0.59 among three varieties to 4.14 to $4.20 \mathrm{mmol} \mathrm{H}_{2} \mathrm{O} / \mathrm{m}^{2} / \mathrm{s}$ for 'CGN 22091' and 'Peruvian Purple' peppers. Water use efficiency (WUE; $P_{n} / E$ ) varied from 2.92 to 3.43 among three varieties to 5.10 to 7.20 for 16 other varieties. $C$. annuum derived varieties had higher $\mathrm{P}_{\mathrm{n}}\left(9.4 \mu \mathrm{mol} \mathrm{CO} \mathrm{CO}_{2} / \mathrm{m}^{2} / \mathrm{s}\right.$ fixed) than varieties derived from other species $\left(4.5-8.6 \mu \mathrm{mol} \mathrm{CO} / \mathrm{m}^{2} / \mathrm{s}\right.$ fixed). Varieties originating from dry climates had higher $\mathrm{P}_{\mathrm{n}}\left(12.5 \mu \mathrm{mol} \mathrm{CO} \mathrm{CO}_{2} / \mathrm{m}^{2} / \mathrm{s}\right.$ fixed) than those originating from temperate or tropical climates $\left(8.0-8.8 \mu \mathrm{mol} \mathrm{CO} / \mathrm{C}^{2} / \mathrm{s}\right.$ fixed). $\mathrm{T}_{\text {leaf }}\left(27\right.$ to $\left.33^{\circ} \mathrm{C}\right)$ and $\mathrm{RH}(38 \%$ to $39 \%$ and $57 \%$ to $59 \%$ ) differed among varieties. $P_{n}$ was positively correlated with $g_{\mathrm{S}}$, $E$, and RH and was negatively correlated with WUE. We found that Capsicum $P_{n}, E$, and $g_{S}$ varied more than has been previously reported, and our data suggested that $P_{n}, g_{S}$, and $E$ data of outdoor-grown peppers should be used only when selecting parents for a breeding program (unless progeny is intended for greenhouse production).
\end{abstract}

Peppers (Capsicum sp.) were one of the first crops domesticated in the Western Hemisphere using several independent, geographically distinct, and regional domestication efforts (Bosland and Votava, 2012). Cultivated peppers are derived from five

\footnotetext{
Received for publication 8 Jan. 2019. Accepted for publication 9 Jan. 2019.

The authors acknowledge and appreciate the financial support of the IRSIP Program of the Higher Education Commission of Pakistan, the Minnesota Agriculture Experiment Station, the Floriculture and Nursery Research Initiative administered by USDA-ARS, Society of Allied Florists American Floral Endowment (SAF/AFE), and the Horticulture Research Institute (HRI), and the Floriculture Research Alliance members who support University of Minnesota Research (Altman Plants, Rocket Farms, Green Circle Growers, and Smith Gardens). J.E. is the corresponding author. E-mail: erwin001@ umn.edu.
}

species (C. annuum L., C. baccatum L., $C$. chinense Jacq., $C$. frutescens $\mathrm{L}$., and $C$. pubescens) among the 32 documented species in the Capsicum genus (Solanaceae family) (Qin et al., 2014). These domestication efforts resulted in peppers becoming a globally important fresh vegetable (fruit) and spice crop that is now consumed by nearly one-quarter of the world's population, with fresh and dry pepper production reaching 32.2 and 3.8 million tons annually, respectively, in 2014 (FAO, 2014). In the United States, 44,800 acres of bell peppers and 19,400 acres of chili pepper were produced in 2015 , with a wholesale value of $\$ 806$ million and $\$ 135$ million, respectively (USDA NASS Report, 2016). Peppers are consumed as a fresh food and contain carbohydrates, fiber, and a variety of nutrients, including antioxidants such as vitamin $C$, vitamin E, $\beta$-carotene, and carotenoids (Carvalho et al., 2011; Howard et al., 2000;
Howard and Wildman, 2007; Kantar et al., 2016; Palevitch and Craker, 1995; Russo and Howard, 2002; Topuz and Ozdemir, 2007; Wahyuni et al., 2011). Other pepper products are consumed as spices, including dried pepper flakes, processed "hot" sauces, and infused/pressed oils, among other products (Bosland, 1996; Zewdie and Bosland, 2001).

Abiotic factors such as low temperatures, high temperatures, salt stress, drought (Serrano et al., 2017), and waterlogging can limit pepper yield (Ou and Zou, 2012; Zhai et al., 2016). For instance, optimal temperatures for pepper photosynthesis range from 25 to $35{ }^{\circ} \mathrm{C}$, and temperatures outside this range can limit the yield; for example, $C$. chinense flower abortion increased 2-fold and fruit set decreased 3-fold when greenhouse temperatures were increased from 30 to $40{ }^{\circ} \mathrm{C}$ (Garruna-Hernandez et al., 2014). Erickson and Markhart (2002) showed that Capcisum flower abortion after pollination was particularly sensitive to high temperatures $\left(33^{\circ} \mathrm{C}\right)$.

We determined whether photosynthetic and water use attributes differed among outdoor-grown pepper varieties that differed in parental species and indigenous climates. Previous studies of Capsicum focused on differences in photosynthetic and water use attributes among species only or varieties within a species. Past Capsicum research often used greenhouse-grown or controlled environment-grown plants. Our research objectives were to: 1) determine whether instantaneous $\mathrm{P}_{\mathrm{n}}, g_{\mathrm{S}}, \mathrm{E}$, WUE meter cuvette $\mathrm{T}_{\text {leaf }}$, and RH of 33 outdoor-grown pepper varieties differed; 2) to determine whether variety photosynthetic and water use attributes differed based on indigenous parents or habitat; and 3) to determine whether pepper photosynthetic and/or water use attributes were correlated with each other.

\section{Materials and Methods}

Thirty-three pepper varieties derived from five species (C. annum L., C. baccatum L., C. chinense Jacq., C. frutescens L., and $C$. pubescens) from three indigenous habitats (dry, temperate, and tropical) were selected (Table 1). Seeds were sourced from different seed producers/suppliers, and the reported species of origin were confirmed by phenotyping of flowers, leaves, and fruits during the experiment (Table 1). Seeds were sown $0.6 \mathrm{~cm}$ deep in Master Garden Premium media (Premier Tech Horticulture, Ltd., Ontario, Canada) in 32-cell trays (one seed per cell; individual cell volume $\left.=150 \mathrm{~cm}^{3}\right)$ in January and February 2017. Trays were then covered with a clear plastic lid $(10 \mathrm{~cm}$ above media) and were placed in a greenhouse ( $23 \pm$ $2{ }^{\circ} \mathrm{C}$ air temperature). After seeds germinated and cotyledons unfolded, the lid was removed and plants were grown for 9 to 14 additional weeks under natural daylight plus $25 \mu \mathrm{mol} \cdot \mathrm{m}^{-2} \cdot \mathrm{s}^{-1}$ supplemental irradiance (0800-0200 HR; Sunblaze T5 fluorescent lights; Sunlight Supply, Inc., WA; +1.62 $\mathrm{mol} \cdot \mathrm{m}^{-2} \cdot \mathrm{d}^{-1}$ daily light integral) in the same greenhouse. After five leaves unfolded, 
Table 1. Variation in the instantaneous photosynthetic rate $\left(\mathrm{P}_{\mathrm{n}} ; \mu \mathrm{mol} \cdot \mathrm{m}^{-2} \cdot \mathrm{s}^{-1}\right)$, stomatal conductance $\left(g_{\mathrm{S}} ; \mathrm{mmol} \mathrm{H}_{2} \mathrm{O} / \mathrm{m}^{2} / \mathrm{s}\right)$, transpiration rate $\left(\mathrm{E} ; \mathrm{mmol} \mathrm{H} \mathrm{H}_{2} \mathrm{O} / \mathrm{m}^{2} / \mathrm{s}\right)$, cuvette leaf temperature $\left(\mathrm{T}_{\text {leaf }},{ }^{\circ} \mathrm{C}\right)$, and relative humidity after $5 \mathrm{~min}(\mathrm{RH} ; \%)$ and water use efficiency (WUE; WUE $\left.=\mathrm{P}_{\mathrm{n}} / \mathrm{E}\right)$ among 33 outdoor-grown pepper varieties that vary in indigenous habitat and species. Indigenous habitats used for analysis are shown as superscript numbers after the variety name ( ${ }^{1}$ desert; ${ }^{2}$ temperature; ${ }^{3}$ tropical; ' unknown).

\begin{tabular}{|c|c|c|c|c|c|c|c|c|}
\hline Variety & Country of Origin & Species & $P_{n}$ & $g_{\mathrm{S}}$ & $\mathrm{E}$ & $\mathrm{T}_{\text {leaf }}$ & $\mathrm{RH}$ & WUE \\
\hline Malawi Piquante $^{T}$ & Malawi & baccatum & $3.6 \mathrm{a}^{\mathrm{z}}$ & $0.02 \mathrm{a}$ & $0.47 \mathrm{a}$ & $31 \mathrm{ab}$ & 44 abcdef & $5.9 \mathrm{~b}$ \\
\hline Antohi Romanian ${ }^{2}$ & Romania & аппиит & $4.3 \mathrm{ab}$ & $0.05 \mathrm{a}$ & $1.40 \mathrm{abc}$ & $32 \mathrm{ab}$ & 42 abcdef & $4.4 \mathrm{ab}$ \\
\hline Pakistan $^{1}$ & Pakistan & аппиит & $4.3 \mathrm{ab}$ & $0.02 \mathrm{a}$ & $0.59 \mathrm{a}$ & $33 \mathrm{~b}$ & $39 \mathrm{abc}$ & $6.3 \mathrm{~b}$ \\
\hline Tabasco $\operatorname{Red}^{3}$ & Mexico & frutescens & $4.5 \mathrm{ab}$ & $0.03 \mathrm{a}$ & $1.03 \mathrm{abc}$ & $32 \mathrm{ab}$ & 42 abcdef & $4.6 \mathrm{ab}$ \\
\hline Hawaiian Sweet Hot $^{3}$ & Hawaii & аппиит & $4.8 \mathrm{abc}$ & $0.03 \mathrm{a}$ & $0.90 \mathrm{ab}$ & $32 \mathrm{ab}$ & $38 \mathrm{a}$ & $5.8 \mathrm{~b}$ \\
\hline Hungarian Sunshine & Hungary & аппиит & $4.8 \mathrm{abc}$ & $0.07 \mathrm{a}$ & $1.75 \mathrm{abc}$ & $30 \mathrm{ab}$ & 44 abcdef & $3.7 \mathrm{ab}$ \\
\hline Red Rocoto ${ }^{3}$ & Ecuador & pubescens & $6.0 \mathrm{abcd}$ & $0.04 \mathrm{a}$ & $1.23 \mathrm{abc}$ & $32 \mathrm{ab}$ & $41 \mathrm{abcd}$ & $4.9 \mathrm{ab}$ \\
\hline Shishitou $^{2}$ & Japan & аппиит & $6.1 \mathrm{abcd}$ & $0.08 \mathrm{abc}$ & $2.03 \mathrm{abc}$ & $32 \mathrm{ab}$ & 45 abcdef & $3.1 \mathrm{a}$ \\
\hline Moses Orange $^{3}$ & Kenya & апnиит & 6.3 abcde & $0.04 \mathrm{a}$ & $1.13 \mathrm{abc}$ & $33 \mathrm{~b}$ & $39 a b$ & $6.0 \mathrm{~b}$ \\
\hline \multicolumn{9}{|l|}{ Trinidad Moruga } \\
\hline Scorpion $^{3}$ & Trinidad & chinense & 7.7 abcdef & $0.05 \mathrm{a}$ & $1.27 \mathrm{abc}$ & $32 \mathrm{ab}$ & 42 abcdef & $7.2 \mathrm{~b}$ \\
\hline Jamaican Red Hot ${ }^{3}$ & Jamaica & chinense & 7.7 abcdef & $0.03 \mathrm{a}$ & $1.05 \mathrm{abc}$ & $33 \mathrm{~b}$ & 40 abcd & $6.8 \mathrm{~b}$ \\
\hline Apple Hungarian ${ }^{2}$ & Hungary & аппиит & 7.9 abcdef & $0.05 \mathrm{a}$ & $1.50 \mathrm{abc}$ & $32 \mathrm{ab}$ & 42 abcdef & $5.7 \mathrm{~b}$ \\
\hline \multicolumn{9}{|l|}{ Giant Mexican } \\
\hline Rocoto & Mexico & pubescens & 10.4 abcdef & $0.16 \mathrm{abc}$ & $2.73 \mathrm{abc}$ & $28 \mathrm{a}$ & 54 abcdef & $5.5 \mathrm{~b}$ \\
\hline \multicolumn{9}{|l|}{ Bebere Ethiopian } \\
\hline Brown $^{1}$ & Ethiopia & аппиит & $10.5 \mathrm{abcdefg}$ & $0.17 \mathrm{abc}$ & $3.60 \mathrm{abc}$ & $32 \mathrm{ab}$ & 45 abcedf & $3.71 \mathrm{a}$ \\
\hline \multicolumn{9}{|l|}{ Czechoslovakian } \\
\hline Black $^{2}$ & Czech Rep. & аппиит & 10.7 bcdefg & $0.10 \mathrm{abc}$ & $2.21 \mathrm{abc}$ & $28 \mathrm{ab}$ & 54 abcdef & $5.17 \mathrm{ab}$ \\
\hline Zimbabwe Bird $^{3}$ & Zimbabwe & аппиит & 10.8 bcdefg & $0.14 \mathrm{abc}$ & $3.32 \mathrm{abc}$ & $32 \mathrm{ab}$ & 45 abcdef & $3.43 \mathrm{a}$ \\
\hline Goronong $^{3}$ & Malaysia & chinense & 10.9 bcdefg & $0.19 \mathrm{abc}$ & $2.85 \mathrm{abc}$ & $28 \mathrm{ab}$ & 55 abcdef & $4.48 \mathrm{ab}$ \\
\hline Bolivian Rainbow $^{1}$ & Bolivia & аппиит & $11.1 \mathrm{bcdefg}$ & $0.13 \mathrm{abc}$ & $2.27 \mathrm{abc}$ & $28 \mathrm{ab}$ & $57 \mathrm{def}$ & $4.61 \mathrm{ab}$ \\
\hline CGN $22091^{3}$ & Costa Rica & chinense & 11.5 cdefg & $0.21 \mathrm{abc}$ & $4.14 \mathrm{c}$ & $31 \mathrm{ab}$ & 49 abcdef & $2.92 \mathrm{a}$ \\
\hline Pepperoncini $^{2}$ & Italy & annuum & 12.6 defg & $0.19 \mathrm{abc}$ & $3.09 \mathrm{abc}$ & $27 \mathrm{a}$ & 56 bcdef & $4.84 \mathrm{ab}$ \\
\hline Numex Sunset Chili & USA & anпuит & $13.1 \mathrm{efg}$ & $0.20 \mathrm{abc}$ & $3.11 \mathrm{abc}$ & $28 \mathrm{ab}$ & $57 \mathrm{def}$ & $4.69 \mathrm{ab}$ \\
\hline Aleppo $^{1}$ & Syria & апnиит & $13.3 \mathrm{fg}$ & $0.20 \mathrm{abc}$ & $3.13 \mathrm{abc}$ & $29 \mathrm{ab}$ & $57 \mathrm{ef}$ & $4.53 \mathrm{ab}$ \\
\hline Species: & & & $P_{n}$ & & Climate & & $P_{n}$ & $\mathrm{RH}$ \\
\hline аппиит & & & $9.4 \mathrm{c}$ & & Desert & & $12.5 \mathrm{~b}$ & $56 \mathrm{~b}$ \\
\hline baccatum & & & $6.4 \mathrm{ab}$ & & Temperate & & $8.0 \mathrm{a}$ & $47 \mathrm{ab}$ \\
\hline chinense & & & $8.6 \mathrm{ab}$ & & Tropical & & $8.8 \mathrm{ab}$ & $46 \mathrm{a}$ \\
\hline frutescens & & & $4.5 \mathrm{a}$ & & & & & \\
\hline pubescens & & & $8.2 \mathrm{ab}$ & & & & & \\
\hline
\end{tabular}

${ }^{\mathrm{z}}$ Means followed by different lowercase letters within each column are significantly different based on Tukey's honestly significant difference test $(P \leq 0.05)$ for mean separation based on the analysis of variance (ANOVA).

${ }^{\mathrm{y}}$ Statistical significance as determined by analysis.

Ns, *,**,***Nonsignificant or significant at $P \leq 0.05,0.01$, or 0.001 , respectively.

plants were transplanted into $18.9-\mathrm{L}$ plastic pots with the same media. Potted plants were placed outdoors (St. Paul, MN) on 1 June and were watered with a drip irrigation system as needed. Nutrients were provided by incorporating granular Sustane Natural Fertilizer (46-4; Cannon Falls, MN) with media at a rate of $12 \mathrm{~g} / \mathrm{L}$ to provide $\approx 100 \mathrm{ppm}$ of N $(3.2 \mathrm{~N}-$ $6 \mathrm{P}_{2} \mathrm{O}_{5}-4 \mathrm{~K}_{2} \mathrm{O}$ ).

$\mathrm{P}_{\mathrm{n}}, g_{\mathrm{S}}$, and $\mathrm{E}$ data were collected from the third unfolded mature leaf (expansion completed) below the shoot tip using a LI-COR LI6400XT portable gas exchange meter (LICOR, Inc., Lincoln, NE) with an external cuvette with a built-in LED light source (cuvette dimensions $=3 \times 2 \mathrm{~cm}^{2}$ ) on 29 July, 3 Aug., 5 Aug., 10 Aug., 17 Aug., and 22 Aug. 2017 (similar weather conditions). Because data were collected at different times, a different leaf was used each time as the plant grew. Data were recorded $5 \mathrm{~min}$ after placing the cuvette around a leaf $\left(\mathrm{P}_{\mathrm{n}}\right.$ had stabilized). Cuvette $\mathrm{T}_{\text {leaf }}$ and $\mathrm{RH}$ were also recorded at that time. Cuvette irradiance, carbon dioxide concentration, and atmospheric flow rate were set to $1000 \mu \mathrm{mol} \cdot \mathrm{m}^{-2} \cdot \mathrm{s}^{-1}, 400 \mathrm{ppm}$ (approximately outdoor ambient), and 500 $\mu \mathrm{L} \cdot \mathrm{min}^{-1}$, respectively. The outdoor air tem- perature, $\mathrm{RH}$, and photoperiod on collection dates varied from 22.4 to $27.9{ }^{\circ} \mathrm{C}, 40 \%$ to $70 \%$, and 13.25 to $15.5 \mathrm{~h}$, respectively. Garruna-Hernandez et al. (2014) reported that $C$. chinense $g_{\mathrm{S}}$ varied during the day and was highest between 1100 and $1300 \mathrm{HR}$; therefore, we only collected data between 1100 and $1300 \mathrm{HR}$. WUE was calculated by dividing $\mathrm{P}_{\mathrm{n}}$ by $\mathrm{E}$ (Ou and Zou, 2012).

The experiment was organized in a completely randomized statistical design. $\mathrm{P}_{\mathrm{n}}, \mathrm{E}$, $g_{\mathrm{S}}$, and WUE were dependent variables, and variety (33 levels), species of origin (5 levels), and indigenous habitat (3 levels) 
were independent variables (Table 1). Indigenous habitats were subjectively categorized as dry/desert, temperate, and tropical based on the climate in the country of origin (Table 1). Data were collected at six different times from a different leaf each time (198 total values each for $\mathrm{P}_{\mathrm{n}}, \mathrm{E}, g_{\mathrm{S}}$, and WUE). Data were analyzed using an analysis of variance followed by mean separation (Tukey's honestly significant difference and least significant difference; $\alpha<0.05$ ) using the SPSS statistical software package (IBM SPSS Statistics, version 24; IBM Corp., Armonk, NY). Pearson correlations among dependent variables were also determined.

\section{Results}

$P_{n}$ varied from 3.6 to 3.7 for 'Malawi Piquante' and 'Korean Long Green' peppers to $16.3 \mu \mathrm{mol} \mathrm{CO} / \mathrm{m}^{2} / \mathrm{s}$ (fixed) for 'Thai Hot' peppers (Table 1 ). The $g_{\mathrm{S}}$ varied from 0.01 to 0.59 for most varieties (Malawi, Korean Long Green, Antohi Romanian, Pakistan, Fatali, Tabasco Red, HIan Sweet Hot, Hungarian Sunshine, Red Roccoto, Moses Orange, Trinidad Moruga Scorpion, Jamaican Red Hot, and Apple Hungarian) to $0.28 \mathrm{mmol}$ $\mathrm{H}_{2} \mathrm{O} / \mathrm{m}^{2} / \mathrm{s}$ for Thai Hot pepper (Table 1). E varied from 0.43 to 0.59 for 'Malawi Piquante', 'Korean Long Green', and 'Pakistan' peppers to 4.14 and $4.21 \mathrm{mmol} \mathrm{H}_{2} \mathrm{O} / \mathrm{m}^{2}$ / $\mathrm{s}$ for 'CGN 22091' and 'Peruvian Purple' peppers, respectively (Table 1). WUE differed from 2.92 to 3.43 among three varieties to 5.10 to 7.20 for 16 other pepper varieties (Table 1). $\mathrm{T}_{\text {leaf }}$ varied from $27^{\circ} \mathrm{C}$ for 'Thai Hot' and 'Pepperoncini' peppers to $33^{\circ} \mathrm{C}$ for 'Pakistan', 'Moses Orange' and 'Jamaican Red Hot' peppers (Table 1). Cuvette RH differed from 38\% for 'Hawaiian Sweet' peppers to $59 \%$ for 'Thai Hot' peppers (Table 1).

C. frutescens, C. baccatum, C. chinense, and $C$. pubescens derived varieties had lower $\mathrm{P}_{\mathrm{n}}\left(4.5-8.6 \mu \mathrm{mol} \mathrm{CO}_{2} / \mathrm{m}^{2} / \mathrm{s}\right.$ fixed) than $C$. annuum derived varieties $\left(9.4 \mu \mathrm{mol} \mathrm{CO} \mathrm{CO}_{2} / \mathrm{m}^{2} /\right.$ $\mathrm{s}$ fixed) (Table 1). There were no differences in $g_{\mathrm{S}}, \mathrm{E}, \mathrm{T}_{\text {leaf }}, \mathrm{RH}$, or WUE among varieties based on parental species (Table 1). Varieties originating from temperate climates had lower $\mathrm{P}_{\mathrm{n}}\left(8.0 \mu \mathrm{mol} \mathrm{CO}_{2} / \mathrm{m}^{2} / \mathrm{s}\right.$ fixed $)$ than those originating from dry regions (12.5 umol $\mathrm{CO}_{2} / \mathrm{m}^{2} / \mathrm{s}$ fixed) (Table 1 ). Varieties from tropical regions had a lower cuvette $\mathrm{RH}$ (46\% to $47 \%$ ) than those from dry regions $(56 \%)$ (Table 1) when tested in our experiment.

$\mathrm{P}_{\mathrm{n}}$ was positively correlated with $g_{\mathrm{S}}$ (Pearson correlation $=0.88), \mathrm{E}(0.86)$, and RH (0.62), and it was negatively correlated with WUE (-0.35) (Table 2). The $g_{\mathrm{S}}$ was positively correlated with $\mathrm{E}(0.95)$ and $\mathrm{RH}$ (0.56), and it was negatively correlated with $\mathrm{T}_{\text {leaf }}(-0.18)$ and WUE $(-0.56)$ (Table 2). E was positively correlated with RH $(0.44)$ and negatively correlated with WUE $(-0.67)$ (Table 2). $\mathrm{T}_{\text {leaf }}$ was negatively correlated with $g_{\mathrm{S}}(-0.18)$ and RH $(-0.21)$ (Table 2). $\mathrm{RH}$ was negatively correlated with $\mathrm{T}_{\text {leaf }}$ $(-0.21)$ (Table 2).

\section{Discussion}

Capsicum $\mathrm{P}_{\mathrm{n}}$ values varied more in our experiment (3.6-3.7 to $16.3 \mu \mathrm{mol} \mathrm{CO} 2 / \mathrm{m}^{2} / \mathrm{s}$ fixed) than they did in other experiments reported by others; for example, $\mathrm{Ou}$ and Zou (2012) reported that the $P_{n}$ of five Capsicum species varied from 15.8 to 21.8 $\mu \mathrm{mol} \mathrm{CO}_{2} / \mathrm{m}^{2} / \mathrm{s}$ (fixed). Among pepper varieties within a species, $P_{n}$ also varied more in our experiment than it did in others (Ghasemi et al., 2016; Rosado-Souza et al., 2015). Borisev et al. (2012) reported that the $\mathrm{P}_{\mathrm{n}}$ of 10 C. annuum varieties differed from 14.5 to $16.6 \mu \mathrm{mol} \mathrm{CO} / \mathrm{m}^{2} / \mathrm{s}$ (fixed); the $C$. annuum variety $\mathrm{P}_{\mathrm{n}}$ (22 varieties) in our work ranged from 3.7 to $16.3 \mu \mathrm{mol} \mathrm{CO}_{2} / \mathrm{m}^{2} / \mathrm{s}$ (fixed) (Table 1). Ridzuan et al. (2018) reported that the $C$. annuum variety/accession $\mathrm{P}_{\mathrm{n}}$ differed from 11.5 to $19.1 \mu \mathrm{mol} \mathrm{CO}_{2} / \mathrm{m}^{2} / \mathrm{s}$ (fixed). In contrast, Hassan et al. (2014) reported that the $C$. annuum variety $\mathrm{P}_{\mathrm{n}}$ ranged from 2.5 to $5.3 \mu \mathrm{mol} \mathrm{CO}_{2} / \mathrm{m}^{2} / \mathrm{s}$ (fixed; irradiance not reported). Pérez-Grajales et al. (2004) reported similar $\mathrm{P}_{\mathrm{n}}$ rates (at a lower irradiance of $500 \mu \mathrm{mol} / \mathrm{m}^{2} / \mathrm{s}$ ) for C. pubescens. RosadoSouza et al. (2015) reported that the $C$. chinense accession $\mathrm{P}_{\mathrm{n}}$ varied from 17 to 25 $\mu \mathrm{mol} \mathrm{CO} / \mathrm{m}^{2} / \mathrm{s}$ (fixed).

Differences between our $\mathrm{P}_{\mathrm{n}}$ values and others may have been related to the irradiance levels when $P_{n}$ was measured, where plants were grown, or the number of varieties studied. For instance, irradiance in our work was at saturating photosynthetic levels (1000 $\left.\mu \mathrm{mol} \cdot \mathrm{m}^{-2} \cdot \mathrm{s}^{-1}\right)$, whereas irradiance in other

Table 2. Pearson correlation between instantaneous photosynthetic rate $\left(\mathrm{P}_{\mathrm{n}}\right)$, stomatal conductance $\left(g_{\mathrm{S}}\right)$, transpiration rate $(\mathrm{E})$, cuvette leaf temperature $\left(\mathrm{T}_{\text {leaf }}\right)$, and humidity after $5 \mathrm{~min}(\mathrm{RH})$ and water use efficiency (WUE; WUE $\left.=\mathrm{P}_{\mathrm{n}} / \mathrm{T}\right)$.

\begin{tabular}{|c|c|c|c|c|c|c|}
\hline Factor & $P_{n}$ & $g_{\mathrm{S}}$ & $\mathrm{E}$ & $T_{\text {leaf }}$ & $\mathrm{RH}$ & WUE \\
\hline$\overline{\mathrm{P}_{\mathrm{n}}}$ & - & $0.88^{* * z}$ & $0.86^{* *}$ & -0.09 & $0.62 * *$ & $-0.35^{* *}$ \\
\hline (2-tailed) & - & $* * *$ & $* * *$ & NS & $* * *$ & $* * *$ \\
\hline $\mathrm{g}_{\mathrm{s}}$ & - & - & $0.95 * *$ & $-0.18 *$ & $0.56^{* *}$ & $-0.56^{* *}$ \\
\hline (2-tailed) & - & - & $* * *$ & $*$ & $* * *$ & $* * *$ \\
\hline $\mathrm{E}$ & - & - & - & -0.02 & $0.44 * *$ & $-0.67 * *$ \\
\hline (2-tailed) & - & - & - & NS & $* * *$ & $* * *$ \\
\hline $\mathrm{T}_{\text {leaf }}$ & - & - & - & - & $-0.21 * *$ & -0.010 \\
\hline (2-tailed) & - & - & - & - & $* *$ & NS \\
\hline RH & - & - & - & - & - & -0.010 \\
\hline (2-tailed) & - & - & - & - & - & NS \\
\hline
\end{tabular}

${ }^{\mathrm{z}}$ Statistical significance as determined by the analysis of variance.

NS, $* * *, * * *$ Nonsignificant or significant at $P \leq 0.05,0.01$, or 0.001 , respectively. studies was undocumented or at 300 to 500 $\mu \mathrm{mol} \cdot \mathrm{m}^{-2} \cdot \mathrm{s}^{-1}$. Because peppers are typically grown in the field, where they are routinely exposed to saturating irradiance levels, we believe that our data more accurately reflected actual field $\mathrm{P}_{\mathrm{n}}$. Furthermore, $\mathrm{P}_{\mathrm{n}}$ can vary more for field-grown than for greenhouse-grown/controlled environmentgrown Capsicum. Borisev et al. (2012) reported that the $\mathrm{P}_{\mathrm{n}}$ of nine Capsicum varieties differed from 14.5 to $16.6 \mu \mathrm{mol} \mathrm{CO}_{2} / \mathrm{m}^{2} / \mathrm{s}$ (fixed), but that $\mathrm{P}_{\mathrm{n}}$ differed from 12.8 to 18.7 $\mu \mathrm{mol} \mathrm{CO}_{2} / \mathrm{m}^{2} / \mathrm{s}$ (fixed) when those same varieties were grown in the field. Furthermore, the greater variation in $\mathrm{P}_{\mathrm{n}}$ in this study compared with that in some other studies may have occurred because we evaluated a greater number of varieties that were intentionally selected to represent a broad array of genetic and indigenous backgrounds.

Our data regarding the varieties derived from $C$. annuum included collectively higher $\mathrm{P}_{\mathrm{n}}$ than the data regarding the varieties derived from other species. However, broad conclusions regarding which species have higher $P_{n}$ should be made cautiously because abiotic factors can interact with species and affect $\mathrm{P}_{\mathrm{n}}$. For instance, Ou and Zou (2012) reported that the $\mathrm{P}_{\mathrm{n}}$ of $C$. frutescens was higher than that of four other Capsicum species (21.8 vs. $15.8-17.7 \mu \mathrm{mol} \mathrm{CO} / \mathrm{Cm}^{2} / \mathrm{s}$ fixed) when plants were grown at $35^{\circ} \mathrm{C}$, but the $\mathrm{P}_{\mathrm{n}}$ of $C$. pubescens was highest when plants were grown at $15{ }^{\circ} \mathrm{C}$. In the same study, the $\mathrm{P}_{\mathrm{n}}$ of $C$. baccatum and the $\mathrm{P}_{\mathrm{n}}$ of $C$. pubescens were higher than that of three other Capsicum species when plants were drought-stressed. In contrast, Okunlola et al. (2017) reported that the $C$. chinense $\mathrm{P}_{\mathrm{n}}$ was more drought-tolerant than the $\mathrm{P}_{\mathrm{n}}$ of $C$. annuum or $C$. frutescens. The environment where a plant is grown or the water status of a plant when $P_{n}$ data are collected can lead to different conclusions about which Capsicum species has higher $\mathrm{P}_{\mathrm{n}}$. Although varieties are reportedly derived from a species, many are interspecific hybrids (often unreported) (Petkova et al., 2014) and genetically related (Amarul J'unior et al., 2005). That hybridization alone may impact the photosynthetic or water use data. Petkova et al. (2014) showed that the $\mathrm{P}_{\mathrm{n}}$ of four $\mathrm{F}_{1}$ pepper hybrids was more tolerant to high temperatures (33 to $35^{\circ} \mathrm{C}$ ) than that of parental species.

The range and $g_{\mathrm{S}}$ values reported in our study $\left(0.01-0.28 \mathrm{mmol} \mathrm{H}_{2} \mathrm{O} / \mathrm{m}^{2} / \mathrm{s}\right)$ were less than those reported by others. Ridzuan et al. (2018) reported that the $g_{\mathrm{S}}$ of the $C$. annuum variety (14) varied from 0.25 to $0.68 \mathrm{mmol}$ $\mathrm{H}_{2} \mathrm{O} / \mathrm{m}^{2} / \mathrm{s}$. Hassan et al. (2014) reported that the $g_{\mathrm{S}}$ of the $C$. annuum variety varied from 0.50 to $0.60 \mathrm{mmol} \mathrm{H}_{2} \mathrm{O} / \mathrm{m}^{2} / \mathrm{s}$. Differences between our $g_{\mathrm{S}}$ data and that of others may have been related to the environments where plants were grown. For instance, plants grown at temperatures below $15^{\circ} \mathrm{C}$ or above the optimal temperature for pepper $\mathrm{P}_{\mathrm{n}}$ can decrease the Capsicum $g_{\mathrm{S}}$ (Jaimez and Rada, 2016). Because the $T_{\text {leaf }}$ data were collected on some days when the temperature was above the optimal temperature reported for 
Table 3. Variation in instantaneous photosynthetic rate $\left(\mathrm{P}_{\mathrm{n}} ; \mu \mathrm{mol} \mathrm{CO} \mathrm{CO}_{2} / \mathrm{m}^{2} / \mathrm{s}\right.$ fixed), stomatal conductance $\left(g_{\mathrm{S}} ; \mathrm{mmol} \mathrm{H} \mathrm{H}_{2} \mathrm{O} / \mathrm{m}^{2} / \mathrm{s}\right)$, transpiration rate $\left(\mathrm{E} ; \mathrm{mmol} \mathrm{H}_{2} \mathrm{O} / \mathrm{m}^{2} / \mathrm{s}\right)$, cuvette leaf temperature $\left(\mathrm{T}_{\text {leaf }} ;{ }^{\circ} \mathrm{C}\right)$, and relative humidity (RH; \%) and water use efficiency (WUE; WUE $=\mathrm{P}_{\mathrm{n}} / \mathrm{E}$ ) among 33 outdoor-grown pepper varieties.

\begin{tabular}{|c|c|c|c|c|c|c|c|}
\hline \multicolumn{8}{|c|}{ Collection dates } \\
\hline & 29 July & 3 Aug. & 5 Aug. & 10 Aug. & 17 Aug. & 22 Aug. & Significance \\
\hline Factor & Rep 1 & Rep 2 & Rep 3 & Rep 4 & Rep 5 & Rep 6 & \\
\hline$P_{n}$ & $8.7 \mathrm{abc}^{2}$ & $9.2 \mathrm{abc}$ & $11.1 \mathrm{c}$ & $10.3 \mathrm{bc}$ & $7.4 \mathrm{ab}$ & $6.9 \mathrm{a}$ & $* * \mathrm{y}$ \\
\hline$g_{\mathrm{S}}$ & $0.13 \mathrm{ab}$ & $0.15 \mathrm{~b}$ & $0.13 \mathrm{ab}$ & $0.13 a b$ & $0.7 \mathrm{ab}$ & $0.7 \mathrm{a}$ & ** \\
\hline $\mathrm{E}$ & $2.28 \mathrm{a}$ & $2.47 \mathrm{a}$ & $2.33 \mathrm{a}$ & $2.67 \mathrm{a}$ & $1.48 \mathrm{a}$ & $1.52 \mathrm{a}$ & $*$ \\
\hline $\mathrm{T}_{\text {leaf }}$ & $27.7 \mathrm{a}$ & $28.8 \mathrm{a}$ & $34.0 \mathrm{~b}$ & $33.6 \mathrm{~b}$ & $29.6 \mathrm{a}$ & $28.5 \mathrm{a}$ & $* * *$ \\
\hline $\mathrm{RH}$ & $43 \mathrm{ab}$ & $50 \mathrm{c}$ & $58 \mathrm{~d}$ & $49 \mathrm{bc}$ & $48 \mathrm{bc}$ & $40 \mathrm{a}$ & $* * *$ \\
\hline WUE & $4.33 \mathrm{a}$ & $4.41 \mathrm{a}$ & $5.55 \mathrm{ab}$ & $4.48 \mathrm{ab}$ & $6.12 \mathrm{~b}$ & $5.38 \mathrm{ab}$ & $* *$ \\
\hline
\end{tabular}

${ }^{\mathrm{z}}$ Means followed by different letters within each row are statistically different based on Tukey's honestly significant different test $(P \leq 0.05)$ for mean separation.

${ }^{y}$ Statistical significance as determined by analysis of variance.

Ns, ${ }^{*}, * *, * *$ Nonsignificant or significant at $P \leq 0.05,0.01$, or 0.001 , respectively.

Capsicum $\mathrm{P}_{\mathrm{n}}\left(25\right.$ to $\left.30^{\circ} \mathrm{C}\right)$, the $g_{\mathrm{S}}$ may have been impacted (Table 3 ).

Our data indicated that $g_{\mathrm{S}}$ does not vary among domesticated Capsicum species (Table 1). Milla et al. (2013) also found that $g_{\mathrm{S}}$ did not vary between wild-type and domesticated $C$. annuum or C. baccatum. Interestingly, we observed that $g_{\mathrm{S}}$ differed among varieties derived from those species. Rosado-Souza et al. (2015) reported that the C. annuum variety $g_{\mathrm{S}}$ differed. Furthermore, Kang et al. (2001) reported that the $C$. chinense variety $g_{\mathrm{S}}$ differed. Yet, in both of those studies, the species $g_{\mathrm{S}}$ did not differ. Similarly, Percy et al. (1996) showed that the $g_{\mathrm{S}}$ of interspecific selections of cotton (Gossypium barbadense $\mathrm{L}$ ) was higher than that of the parents or ancestral lines. Differences in the $g_{\mathrm{S}}$ of varieties observed by us and others may have been due to the integration of a mutation into breeding programs over time and/or interspecific hybridization resulting in greater variations in $g_{S}$ than that observed for genetic parents. Furthermore, a recent study has shown a transgenerational effect on watercress (Lepidium sativum) $g_{\mathrm{S}}$; the maternal light environment effects on stomatal density and $g_{\mathrm{S}}$ were expressed in seedpropagated progeny, suggesting that differences in $g_{\mathrm{S}}$ in this experiment and in past experiments, to some degree, may be impacted by the environment in which seeds were produced (Vrablova et al., 2018). A similar relationship between the maternal water status and progeny WUE was also reported for Eucalyptus (Vivas et al., 2019).

The $\mathrm{E}$ values reported here also varied more than those reported by others, although the maximum $\mathrm{E}$ values were similar (3.21$4.05 \mathrm{mmol} \mathrm{H}_{2} \mathrm{O} / \mathrm{m}^{2} / \mathrm{s}$ ) (Ou and $\mathrm{Zou}, 2012$ ). Ridzuan et al. (2018) reported that the E of the $C$. annuum variety differed from 4.61 to $7.11 \mathrm{mmol} \mathrm{H}_{2} \mathrm{O} / \mathrm{m}^{2} / \mathrm{s}$ (indoor-grown). Furthermore, differences in $\mathrm{E}$ values in our work and that of others may have been related to where plants were grown. Borisev et al. (2012) reported that the E of Capsicum variety (nine) differed more for outdoorgrown than indoor-grown peppers (4.4-6.1 vs. 4.7-5.0 $\mathrm{mmol} \mathrm{H}_{2} \mathrm{O} / \mathrm{m}^{2} / \mathrm{s}$, respectively).

In contrast to the $\mathrm{P}_{\mathrm{n}}, \mathrm{E}$, and $g_{\mathrm{S}}$ data presented here, the WUE values we observed (3.1-7.2) were similar to those reported by others for peppers grown in a controlled environment (3.9-6.8) (Ou and Zou, 2012). However, our values were generally higher than those reported by Borisev et al. (2012) who also reported that the WUE of indoorgrown $C$. annuum variety (nine) varied less than that of field-grown plants (3.2-3.5 and 2.3-3.9, respectively). The WUE of Capsicum is reportedly impacted by irradiance; WUE was higher when plants were grown under high irradiance $\left(400 \mu \mathrm{mol} \cdot \mathrm{m}^{-2} \cdot \mathrm{s}^{-1} ; 2.2\right)$ compared to low irradiance $\left(200 \mu \mathrm{mol} \cdot \mathrm{m}^{-2} \cdot \mathrm{s}^{-1}\right.$; 1.8) (Fu et al., 2010). However, irradiance in our study was $1000 \mu \mathrm{mol} \cdot \mathrm{m}^{-2} \cdot \mathrm{s}^{-1}$; therefore, it would be considered high. Moreover, the negative correlation between Capsicum WUE and $P_{n}$ that we observed agreed with the observations of Antony and Singandhupe (2004).

Ridzuan et al. (2018) reported that the $C$. annuum variety $\mathrm{E}$ and $g_{\mathrm{S}}$ were correlated with $\mathrm{P}_{\mathrm{n}}$, as we observed ( 0.55 and 0.87 , respectively). However, $P_{n}$ is not always correlated with $g_{\mathrm{S}}$. Yun and Ahn (2009) reported that increasing temperature and atmospheric $\mathrm{CO}_{2}$ concentrations increased the pepper $\mathrm{P}_{\mathrm{n}}$, but not the pepper $g_{\mathrm{S}}$. The strong correlation between pepper $g_{\mathrm{S}}$ and $\mathrm{P}_{\mathrm{n}}$ reported here $(0.95)$ (Table 2) supports the assertion that $g_{\mathrm{S}}$ limitations may reduce pepper $\mathrm{P}_{\mathrm{n}}$ (Serrano et al., 2017). However, the observations of Yun and Ahn (2009) suggested that $g_{S}$ limitations on $\mathrm{P}_{\mathrm{n}}$ may occur less if $\mathrm{CO}_{2}$ concentrations are increased, as is common for greenhouse-produced bell peppers (Dorais, 2003; Erwin and Gesick, 2017).

A negative correlation between $g_{\mathrm{S}}$ and $\mathrm{T}_{\text {leaf }}$ was previously reported $\left(\mathrm{r}^{2}=0.76\right)$ for cotton ( $G$. barbadense L.-derived) (Radin et al., 1994), although that correlation was greater than what we observed here for pepper (Table 2). Interestingly, some have suggested that $g_{\mathrm{S}}$ measurements obtained later in the afternoon (after $1300 \mathrm{HR}$ ) may be important when evaluating plants for higher yield based on $g_{\mathrm{S}}$; for instance, Rebetzke et al., (2003) recommended that wheat breeding projects should involve selected progeny with higher $g_{\mathrm{S}}$ collected later in the day because $g_{\mathrm{S}}$ collected later in the day correlated more with yield than $g_{\mathrm{S}}$ collected earlier. Similarly, Radin et al. (1994) found that the cotton yield (related to $\mathrm{P}_{\mathrm{n}}$ ) was associated more with $g_{\mathrm{S}}$ collected in the afternoon than in the morning, and that varieties with high yield under hot temperatures had higher $g_{\mathrm{S}}$ in the afternoon, but not in the morning ( $\mathrm{Lu}$ et al., 1997). We collected data when $\mathrm{P}_{\mathrm{n}}$ and $g_{\mathrm{S}}$ were highest during the day; whether Capsicum yield is associated more with $g_{S}$ collected at certain times of the day is not known.

Differences in outdoor environmental conditions for data collection dates during our experiment may have reduced the resolution of our experiment. $\mathrm{T}_{\text {leaf }}$ was higher on collection dates 3 and $4\left(33.6\right.$ to $34{ }^{\circ} \mathrm{C}$; overreported $\mathrm{P}_{\mathrm{n}}$ optima) than on other dates $(27.7$ to $29.6{ }^{\circ} \mathrm{C}$ ) (Table 3). Furthermore, cuvette RH was higher on collection dates 2,3 , 4, and $5(48 \%$ to $58 \%)$ than on collection dates 1 and $6(40 \%$ to $43 \%)$ (Table 3$)$. Because $\mathrm{T}_{\text {leaf }}$ and $\mathrm{RH}$ are correlated with $\mathrm{P}_{\mathrm{n}}, g_{\mathrm{S}}$, and $\mathrm{E}$ (Table 2), the environmental differences among collection dates may have impacted values.

Care should be taken when determining conclusions about plant photosynthesis or yield based on instantaneous $\mathrm{P}_{\mathrm{n}}$ or water use data based on the leaf area per unit. Collecting data based on the leaf area per unit does not account for differences in the individual leaf area, plant leaf number, whole-plant leaf area, or whole-plant photosynthesis. Furthermore, instantaneous $\mathrm{P}_{\mathrm{n}}$ data do not account for plant acclimation to changing environmental conditions (Hikosaka et al., 2006). Therefore, our study is of value because it compared photosynthetic and water use attributes of a larger number of pepper varieties at the same time of day and under the same environmental conditions simultaneously. Our study also demonstrated that outdoor-grown pepper variety photosynthetic and water use attributes vary more than previously reported, and that the reported parental species and indigenous habitat are associated with some photosynthetic and water use attributes.

\section{Literature Cited}

Amarul J'unior, A.T., R. Rodrigues, C.P. Sudr'e, E.M. Riva, and M. Karasawa. 2005. Genetic divergence between "chilli" and sweet pepper accessions using multivariate techniques. Hort. Bras. 23(1):22-27.

Antony, E. and R.B. Singandhupe. 2004. Impact of drip and surface irrigation on growth, yield and WUE of capsicum (Capsicum annum L.). Agr. Water Mgt. 65(2):121-132.

Borisev, M., B. Krstic, D. Gvozdenova, and J. Gvozdanovic-Varga. 2012. Photosynthesis and water use efficiency relations to yield of ten pepper varieties (Capsicum annuum). Bulg. J. Agr. Sci. 18(4):589-594.

Bosland, P.W. 1996. Capsicums: Innovative uses of an ancient crop, p. 479-487. In: J. Janick (ed.). Progress in new crops. ASHS Press, Arlington, VA.

Bosland, P.W. and E.J. Votava. 2012. Peppers: Vegetable and spice capsicums. CAB Intl., Wallingford, UK.

Carvalho, J.A., F.C. Rezende, R.F. Aquino, W.A. Freitas, and E.C. Olivera. 2011. Productive and economic analysis of red-pepper under different irrigation depths cultivated in greenhouse. Rev. Bras. Eng. Agr. Ambient. 15:569-574. 
Dorais, M. 2003. The use of supplemental lighting for vegetable crop production: Light intensity, crop response, nutrition, crop management, cultural practices. Can Greenhouse Conf. 2003:1-8.

Erickson, A.N. and A.H. Markhart. 2002. Flower developmental stage and organ sensitivity of bell pepper (Capsicum annuum L.) to elevated temperature. Plant Cell Environ. 25: 123-130.

Erwin, J. and E. Gesick. 2017. Photosynthetic responses of Swiss chard, kale, and spinach cultivars to irradiance and carbon dioxide concentration. HortScience 52:706-712.

Food and Agriculture organization (FAO). 2014. FAOSTAT - Agriculture $<$ http://www.fao.org $>$.

Fu, Q.S., B. Zhao, Y.J. Wang, S. Ren, and Y.D. Guo. 2010. Stomatal development and associated photosynthetic performance of capsicum in response to different light availabilities. Photosynthetica 48(2):189-198.

Garruna-Hernandez, R., R. Orellana, A. LarqueSaavedra, and A. Canto. 2014. Understanding the physiological responses of a tropical crop (Capsicum chinense Jacq.) at high temperature. PLoS One 9(11):e111402.

Ghasemi, M., M. Modarresi, B. Jelodar, N. Bagheri, and A. Jamali. 2016. The evaluation of exogenous application of salicylic acid on physiological characteristics, proline and essential oil content of chamomile (Matricaria chamomila L.) under normal and heat stress conditions. Agriculture 6(3):31.

Hassan, M., T. Haider, S.N. Chowdhury, F. Howlander, and A.F.M. Uddin. 2014. Study on morphophysiological and yield performance of four chilli (Capsicum spp.) lines. J. Biosci. and Agr. Research 2(1):1-7.

Hikosaka, K., K. Ishikawa, A. Borjigidai, O. Muller, and Y. Onoda. 2006. Temperature acclimation of photosynthesis: Mechanisms involved in the changes in temperature dependence of photosynthetic rate. J. Expt. Bot. 57:291-302.

Howard, L.R., S.T. Talcott, C.H. Brenes, and B. Villalon. 2000. Changes in phytochemical and antioxidant activity of selected pepper cultivars (Capsicum species) as influenced by maturity. J. Agr. Food Chem. 48:1713-1720.

Howard, L.R. and R.E.C. Wildman. 2007. Antioxidant vitamin and phytochemical content of fresh and processed pepper fruit (Capsicum annuит), p. 165-191. In: R.E.C. Wildman (ed.). Handbook of Nutraceuticals and Functional Foods. CRC Press, Boca Raton.

Jaimez, R.E. and F. Rada. 2016. Gas exchange, growth, flowering and fruit production in sweet pepper (Capsicum chinense Jacq.) along a thermal gradient determined by altitudinal differences in a tropical region. Expt. Agr. 52(2):251-265.

Kang, S., L. Zhang, X. Hu, Z. Li, and P. Jerie. 2001. An improved water use efficiency for hot pepper grown under controlled alternate drip irrigation on partial roots. Scientia Hort. 89(4):257-267.

Kantar, M.B., J.E. Anderson, S.A. Lucht, K. Mercer, V. Bernau, K.A. Case, N.C. Le, M.K.
Frederiksen, H.C. DeKeyser, Z.Z. Wong, J.C. Hastings, and D.J. Baumler. 2016. Vitamin Variation in Capsicum spp. provides opportunities to improve nutritional value of human diets. PLoS One 11(8):e0161464.

Lu, Z., J. Chen, R.G. Percy, and E. Zeiger. 1997. Photosynthetic rate, stomatal conductance and leaf area of two cotton species (Gossypium barbadense and Gossypium hirsutum) and their relation with heat resistence and yield. Austral. J. Plant Physiol. 24(5):693-700.

Milla, R., N. deDiego-Vico, and N. Martin-Robles. 2013. Shifts in stomatal traits following the domestication of plant species. J. Expt. Bot. 64(11):3137-3146.

Okunlola, G.O., O.A. Olatunji, R.O. Akinwale, A. Tariq, and A.A. Adelusi. 2017. Physiological response of the three most cultivated pepper species (Capsicum spp.) in Africa to drought stress imposed at three stages of growth and development. Scientia Hort. 224:198-205.

Ou, L.J. and X.X. Zou. 2012. The photosynthetic stress responses of five pepper species are consistent with their genetic variability. Photosynthetica 50(1):49-55.

Palevitch, D. and L.E. Craker. 1995. Nutritional and medicinal importance of red pepper (Capsicum spp.). J. Herbs Spices Med. Plants 3:5583.

Percy, R.G., Z. Lue, J.W. Radin, E. Turcotte, and E. Zeiger. 1996. Inheritance of stomatal conductance in cotton (Gossypium barbadense). Physiol. Plant. 96(3):389-394.

Pérez-Grajales, M., V.A. González-Hernández, M.C. Mendoza-Castillo, C. Peña Valdivia, A. Peña-Lomelí, and J. Sahagún-Castellanos. 2004. Physiological characterization of manzano hot pepper (Capsicum pubescens $\mathrm{R} \& \mathrm{P}$ ) landraces. J. Amer. Soc. Hort. Sci. 129:88-92.

Petkova, V., V. Todorova, and N. Tomlekova. 2014. Efficiency of photosynthetic apparatus of sweet pepper (Capsicum annuum L.) $\mathrm{F}_{1}$ hybrids and their parental components in high temperature conditions. Plant Science (Bulgaria).

Qin, C., Y. Changshui, Y. Shen, X. Fang, L. Chen, J. Min, J. Cheng, S. Zhao, M. Xu, Y. Luo, Y. Yang, Z. Wu, L. Mao, H. Wu, C. Ling-Hu, H. Zhou, H. Lin, S. González-Morales, D.L. Trejo-Saavedra, H. Tian, X. Tang, M. Zhao, Z. Huang, A. Zhou, X. Yao, J. Cui, W. Li, Z. Chen, Y. Feng, Y. Niu, S. Bi, X. Yang, W. Li, H. Cai, X. Luo, S. Montes-Hernández, M.A. Leyva-González, Z. Xiong, X. He, L. Bai, S. Tan, X. Tang, D. Liu, J. Liu, S. Zhang, M. Chen, L. Zhang, L. Zhang, Y. Zhang, W. Liao, Y. Zhang, M. Wang, X. Lu, B. Wen, H. Liu, H. Luan, Y. Zhang, S. Yang, X. Wang, J. Xu, X. Li, S. Li, J. Wang, A. Palloix, P.W. Bosland, Y. Li, A. Krogh, R.F. RiveraBustamante, L. Herrera-Estrella, Y. Yin, J. Yu, K. Hu, and Z. Zhang. 2014. Whole-genome sequencing of cultivated and wild peppers provides insights into Capsicum domestication and specialization. Proc. Natl. Acad. Sci. USA 111(14):5135-5140.

Radin, J.W., Z. Lu, R.G. Percy, and E. Zeiger. 1994. Genetic variability for stomatal conduc- tance in Pima cotton and its relation to improvements of heat adaptation. Proc. Natl. Acad. Sci. USA 91:7217-7221.

Rebetzke, G.J., A.G. Condon, R.A. Richards, and G.D. Farquhar. 2003. Gene action for leaf conductance in three wheat crosses. Austral. J. Agr. Res. 54(4):381-387.

Ridzuan, R., M.R. Yusop, M.M. Yusof, S.I. Ismail, G. Miah, and M. Usman. 2018. Genetic diversity analysis of selected Capsicum annuиm genotypes based on morpho-physiological, yield characteristics and their biochemical properties. J. Sci. Food Agr., doi: 10.1002/ jsfa.9169.

Rosado-Souza, L., F. Scossa, I.S. Chaves, S. Kleessen, L.F. Salvador, J.C. Milagre, F. Finger, L.L. Bhering, R. Sulpice, W.L. Araújo, and Z. Nikoloski. 2015. Exploring natural variation of photosynthetic, primary metabolism and growth parameters in a large panel of Capsicum chinense accessions. Planta 242(3):677-691.

Russo, V.M. and L.R. Howard. 2002. Carotenoids in pungent and non-pungent peppers at various developmental stages grown in the field and glasshouse. J. Sci. Food Agr. 82:615-624.

Serrano, L.L., C. Penella, A.S. Bautista, S.L. Galarza, and A.C. Chover. 2017. Physiological changes of pepper accessions in response to salinity and water stress. Span. J. Agr. Res. 15(3):1-10.

Topuz, A. and F. Ozdemir. 2007. Assessment of carotenoids, capsaicinoids and ascorbic acid composition of some selected pepper cultivars (Capsicum annuum L.) grown in Turkey. J. Food Compos. Anal. 20:596-602.

USDA NASS Report. 2016. http://usda.mannlib.cornell.edu/MannUsda/viewDocumentInfo.do?documentID=1177.

Vivas, M., V. Rolo, M.J. Wingfield, and B. Slippers. 2019. Maternal environment regulates morphological and physiological traits in Eucalyptus grandis. For. Ecol. Mgt. 432:631-636.

Vrablova, M., M. Hronkova, D. Vrabl, J. Kubasek, and J. Santrucek. 2018. Light intensity-regulated stomatal development in three generations of Lepidium sativum. Environ. Expt. Biol. 156:316-324.

Wahyuni, Y., A.R. Ballester, E. Sudarmonowati, R.J. Bino, and A.G. Bovy. 2011. Metabolite biodiversity in pepper (Capsicum) fruits of thirty-two diverse accessions: Variation in health-related compounds and implications for breeding. Phytochemistry 72:1358-1370.

Yun, S. and M. Ahn. 2009. Effects on net photosynthesis in field-grown hot pepper responding to increased $\mathrm{CO}_{2}$ and temperature. Korean $\mathrm{J}$. Environ. Agri. 28(2):106-112.

Zewdie, Y. and P.W. Bosland. 2001. Capsaicinoid profiles are not good chemotaxonomic indicators for Capsicum species. Biochem. Syst. Ecol. 29:161-169.

Zhai, Y., M. Guo, H. Wang, J. Lu, J. Liu, C. Zhang, Z. Gong, and M. Lu. 2016. Autophagy, a conserved mechanism for protein degradation, responds to heat, and other abiotic stresses in Capsicum annuum L. Front. Plant Sci. 7:131, doi: 10.3389/ fpls.2016.00131. 